\title{
ONE YEAR FOLLOW-UP STUDY OF QUALITY OF LIFE AMONG OPIOID SUBSTITUTION THERAPY CLIENTS
}

\author{
Sukrant Vir1, Rajiv Arora², Parshottam Dass Garg ${ }^{3}$ \\ 13rd Year Junior Resident, Department of Psychiatry, Government Medical College, Amritsar. \\ ${ }^{2}$ Assistant Professor, Department of Psychiatry, Government Medical College, Amritsar. \\ 3 Professor and HOD, Department of Psychiatry, Government Medical College, Amritsar.
}

\section{BACKGROUND}

ABSTRACT

Opioid Substitution Therapy (OST) is a process in which opioid-dependent injecting drug users (IDUs) are provided with longacting opioid agonist medications like buprenorphine for a long period of time under medical supervision along with psycho-social interventions. The QOL is impaired among opioid dependent IDUs. The present study was undertaken to determine the quality of life among IDUs on opioid substitution therapy.

The aim of this study is to see changes in Quality of Life of Opioid-Dependent IDUs attending OST Centre of a Tertiary Government Hospital over a year.

\section{MATERIALS AND METHODS}

A prospective observational study was conducted on 100 patients attending the OST centre of a tertiary government hospital, who were being administered buprenorphine. Identification data was obtained at baseline and QOL scores obtained using WHOQOLBREF at baseline and at four follow-ups, i.e. after 3 months, 6 months, 9 months and 1 year. After excluding the dropouts, 68 subjects were taken into account to assess QOL. A repeated measuring design (Analysis of Variance) was applied to assess changes in the quality of life at baseline and at follow-ups.

\section{RESULTS}

Scores of WHOQOL-BREF when compared from baseline to end of the study showed statistically significant ( $\mathrm{p}<0.01$ ) improvement in all the four domains of WHOQOL-BREF, i.e. physical, psychological, social and environment.

\section{CONCLUSION}

The present study indicates that buprenorphine is a useful long-term maintenance treatment for opioid dependent IDUs. So OST programmes should be expanded further for curbing injecting drug use and improving quality of life.

\section{KEYWORDS}

OST, IDU, WHOQOL-BREF, Buprenorphine.

HOW TO CITE THIS ARTICLE: Vir S, Arora R, Garg PD. One year follow-up study of quality of life among opioid substitution therapy clients. J. Evolution Med. Dent. Sci. 2018;7(02):131-134, DOI: 10.14260/jemds/2018/29

\section{BACKGROUND}

Substance dependence continues to be a major clinical and social problem affecting millions of people worldwide and causing substantial costs to society. In India, Department of AIDS Control defines an IDU as a person who has used any psychoactive substance through injecting route for nonmedical purpose at least once in the last three months. ${ }^{1} \mathrm{~A}$ large number of the IDUs use opioids as the drug of choice primarily. OST is a process in which opioid-dependent injecting drug users are provided with long-acting opioid agonist medications like methadone or buprenorphine for a long period of time under medical supervision. According to WHOQOL, Quality of Life is a broad concept affected in a complex way including person's physical health, psychological state, level of independence and their relationships to salient features of their environment. ${ }^{2}$

'Financial or Other Competing Interest': None.

Submission 27-11-2017, Peer Review 21-12-2017,

Acceptance 27-12-2017, Published 08-01-2018.

Corresponding Author:

Sukrant Vir,

$3^{\text {rd }}$ Year Junior Resident,

Department of Psychiatry,

Government Medical College, Amritsar.

E-mail:drsukrant@gmail.com

DOI: $10.14260 /$ jemds $/ 2018 / 29$

(c) $(1)(-)$
The QOL is severely impaired among substance users and opioid dependent subjects. The rates of dissatisfaction with life are higher among opioid dependent persons as compared to the general population. It has been found that QOL among IDUs improve when they are maintained on OST.3,4,5,6,7,8,9,10

\section{Aims and Objectives}

1. To study socio-demographic variables of OpioidDependent individuals attending Opioid Substitution Therapy (OST) Centre of a Tertiary Government Hospital.

2. To study changes in Quality of Life in Opioid-Dependent Injecting Drug Users attending the said OST centre over a year.

\section{MATERIALS AND METHODS}

After taking approval from Institutional Ethics and Thesis Committee, a prospective observation study was conducted among Injecting Drug Users at Opioid Substitution Therapy Centre of a Tertiary Government Hospital from July 2016 to June 2017. Out of the total 1603 clients registered with and attending the OST centre, every sixth individual who satisfied selection criteria was included in the study to a total of 100 subjects. OST clients of age 18 years and above who gave the written informed consent were included and those who had 
not given consent to participate in the study and those with medical condition that required hospitalisation were excluded. At start of the study after obtaining informed consent, all subjects were interviewed for socio-demographic profile using semi-structured proforma and for Quality of Life using WHOQOL-BREF scale. Follow-up was done for quality of life at 3 months, 6 months, 9 months and one year. At one year of study, after excluding the dropouts, 68 subjects were finally taken into account to assess the quality of life.

\section{Inclusion Criteria}

OST clients of age 18 years and above, attending the OST centre.

\section{Exclusion Criteria}

1. Clients who had not given consent to participate in the study.

2. Clients with medical condition that required hospitalisation.

\section{Tools and Instruments}

1. A semi-structured proforma for Identification and SocioDemographic Profile of the subject.

2. The World Health Organisation Quality of Life (WHOQOL- BREF).

The short version of the World Health Organisation Quality of Life Assessment (WHOQOL-BREF) is an instrument that conceptually fits with the WHO definition of QOL. WHOQOL-BREF is grouped into four domains of QOL (physical health, psychological health, social relationships and environment) and two items which measure overall QOL and general health. The instrument is a self-report questionnaire using a 5-point Likert scale ranging from 1 (not at all) to 5 (completely).

\section{Statistical Analysis}

The analysis of data was computed with the help of statistical 7.0 and SPSS 20. Frequencies and percentages were calculated to assess socio-demographic data. A repeated measures design (ANOVA) was applied to assess the quality of life at baseline, 3 months, 6 months, 9 months and 1 year interval.

\section{RESULTS}

Table no. 1 shows distribution of data according to various socio-demographic variables. All (100\%) subjects studied were male. $65(65.0 \%)$ subjects in this study were in the age group of 21 - 30 years followed by $25(25.0 \%)$ in the age group of 31 - 40 years. Besides this 5 (5.0\%) were in the age group of 41 - 50 years and $5(5.0 \%)$ were more than 50 years of age. Mean age of subjects was 30.88 years. 42 (42.0\%) subjects were educated up to middle school, 20 (20.0\%) up to primary school, 19 (19.0\%) up to senior secondary and 10 (10\%) were graduates and above. Only 9 (9.0\%) subjects were illiterate. More than three-fourth of subjects (78.0\%) were employed. 49 (49.0\%) subjects were married, 46 $(46.0 \%)$ subjects were unmarried and $5(5.0 \%)$ subjects were divorced. $86(86.0 \%)$ subjects lived in a joint family and 14 (14.0\%) lived in nuclear type of family. $40(40.0 \%)$ of the subjects started illicit use of drug between the age of $20-24$ years and $34(34.0 \%)$ between the age of 15 - 19 years, 19 (19.0\%) subjects used opioid for the first time between age of 25 - 29 years and $7(7.0 \%)$ subjects started to use at or after age of 30 years. Mean age of onset of illicit use by subjects was $22.12+4.72$ years. $41(41.0 \%)$ subjects reported using opioid for 5 - 7 years before OST treatment followed by 37 (37.0\%) who used for 2 - 4 years and 22 (22.0\%) subjects has used opioids for 8 or more years before start of OST treatment. Mean total duration of opioid use was $6.37 \pm 4.32$ years. More than two-third of subjects (68.0\%) remained in the study till its completion. Table no. 2 and Graph no. 1 reveals changes in all four domains of WHOQOL-BREF. All the Quality of life indicators (physical, psychological, social and environmental) were low among subjects. At baseline, greater impairment in social relationships domain (mean score 40.33) and environmental domain (mean score 48.66) were observed. The maximum improvement was observed in social relationships domain (40.33 Vs 57.88, p $<0.01)$ followed by physical (59.87 Vs 75.24, p < 0.01) and psychological domain (58.58 Vs 72.81, p < 0.01). Least improvement was observed in environment domain (48.66 Vs 57.26, $\mathrm{p}<0.01$ ).

\begin{tabular}{|c|c|c|}
\hline $\begin{array}{c}\text { Socio-Demographic } \\
\text { Variable }\end{array}$ & $\begin{array}{c}\text { No. of } \\
\text { Subjects }\end{array}$ & $\begin{array}{c}\text { Percentage } \\
\text { (\%) }\end{array}$ \\
\hline \multicolumn{3}{|c|}{ Gender } \\
\hline Male & 100 & 100 \\
\hline Female & 0 & 0 \\
\hline \multicolumn{3}{|c|}{ Age Group } \\
\hline Up to 20 years & 0 & 0 \\
\hline 21-30 years & 65 & 65 \\
\hline $31-40$ years & 25 & 25 \\
\hline 41-50 years & 5 & 5 \\
\hline Above 50 years & 5 & 5 \\
\hline \multicolumn{3}{|c|}{ Education } \\
\hline Illiterate & 9 & 9 \\
\hline Upto Primary & 20 & 20 \\
\hline Upto Middle & 42 & 42 \\
\hline $\begin{array}{l}\text { Upto Senior } \\
\text { Secondary }\end{array}$ & 19 & 19 \\
\hline Graduate and Above & 10 & 10 \\
\hline \multicolumn{3}{|c|}{ Employment Status } \\
\hline Employed & 78 & 78 \\
\hline Unemployed & 22 & 22 \\
\hline \multicolumn{3}{|c|}{ Marital Status } \\
\hline Married & 49 & 49 \\
\hline Unmarried & 46 & 46 \\
\hline Divorced & 5 & 5 \\
\hline \multicolumn{3}{|c|}{ Family Type } \\
\hline Joint & 86 & 86 \\
\hline Nuclear & 14 & 14 \\
\hline \multicolumn{3}{|c|}{ Duration of Opioids Use } \\
\hline 2-4 years & 37 & 37 \\
\hline 5-7 years & 41 & 41 \\
\hline 8 years and above & 22 & 22 \\
\hline \multicolumn{3}{|c|}{$\begin{array}{c}\text { Table 1. Showing Distribution of Data according to Socio- } \\
\text { Demographic Variables }\end{array}$} \\
\hline
\end{tabular}




\begin{tabular}{|c|c|c|c|c|c|c|c|}
\hline $\begin{array}{c}\text { WHOQOL-BREF } \\
\text { Domain }\end{array}$ & $\begin{array}{c}\text { Mean Score } \\
\text { Baseline } \\
\mathbf{N = 1 0 0} \\
\end{array}$ & $\begin{array}{c}\text { Mean Score 3 } \\
\text { Months } \\
\text { N=88 } \\
\end{array}$ & \begin{tabular}{|c|}
$\begin{array}{c}\text { Mean Score 6 } \\
\text { Months } \\
\mathrm{N}=79\end{array}$ \\
\end{tabular} & \begin{tabular}{|c|}
$\begin{array}{c}\text { Mean Score } 9 \\
\text { Months } \\
\mathrm{N}=73\end{array}$ \\
\end{tabular} & \begin{tabular}{|c|} 
Mean Score \\
1 Year \\
$\mathrm{N}=68$
\end{tabular} & $\begin{array}{c}\text { F-ratio } \\
\text { (ANOVA) } \\
\mathrm{N}=68 \\
\end{array}$ & $P$ value \\
\hline Physical & 59.87 & \begin{tabular}{|l|}
68.31 \\
\end{tabular} & 71.97 & 73.95 & 75.24 & 14.236 & $\mathrm{P}<0.01$ \\
\hline Psychological & 58.58 & 66.58 & 69.48 & 70.99 & 72.81 & 15.035 & $\mathrm{P}<0.01$ \\
\hline Social Relationships & 40.33 & 52.89 & 52.55 & 55.70 & 57.88 & 17.621 & $\mathrm{P}<0.01$ \\
\hline Environment & 48.66 & 54.58 & 55.23 & 56.52 & 57.26 & 18.185 & $\mathrm{P}<0.01$ \\
\hline
\end{tabular}

\begin{tabular}{|c|c|c|c|c|c|c|c|c|c|c|c|}
\hline \multirow{3}{*}{ Author } & \multirow{3}{*}{$\begin{array}{c}\text { Follow- } \\
\text { Up } \\
\text { Months }\end{array}$} & \multirow{3}{*}{$\begin{array}{l}\text { OST } \\
\text { Type }\end{array}$} & \multirow{3}{*}{$\begin{array}{l}\text { No. of } \\
\text { Clients }\end{array}$} & \multicolumn{8}{|c|}{ WHOQOL-BREF Scores } \\
\hline & & & & \multicolumn{2}{|c|}{$\begin{array}{l}\text { Physical } \\
\text { Domain }\end{array}$} & \multicolumn{2}{|c|}{$\begin{array}{l}\text { Psychological } \\
\text { Domain }\end{array}$} & \multicolumn{2}{|c|}{$\begin{array}{c}\text { Social } \\
\text { Domain }\end{array}$} & \multicolumn{2}{|c|}{$\begin{array}{c}\text { Environment } \\
\text { Domain }\end{array}$} \\
\hline & & & & Baseline & $\begin{array}{c}\text { Follow- } \\
\text { Up }\end{array}$ & Baseline & $\begin{array}{c}\text { Follow- } \\
\text { Up }\end{array}$ & Baseline & $\begin{array}{c}\text { Follow- } \\
\text { Up }\end{array}$ & Baseline & $\begin{array}{c}\text { Follow- } \\
\text { Up }\end{array}$ \\
\hline $\begin{array}{c}\text { Lua and } \\
\text { Talib, } \\
2012 \\
\end{array}$ & 12 & Methadone & 75 & 12.69 & 14.58 & 11.97 & 14.30 & 12.74 & 13.79 & 11.96 & 13.93 \\
\hline \begin{tabular}{|c|} 
Musa et al, \\
2012 \\
\end{tabular} & 24 & Methadone & 107 & 17.58 & 19.86 & 15.42 & 17.73 & 9.68 & 10.64 & 19.47 & 22.02 \\
\hline \begin{tabular}{|c|} 
Baharom \\
et al, 2012
\end{tabular} & 6 & Methadone & 122 & 12.25 & 14.40 & 12.03 & 14.52 & 12.49 & 13.67 & 12.93 & 14.46 \\
\hline \begin{tabular}{|c|} 
Dvoriak \\
2008 \\
\end{tabular} & 6 & BPN & 76 & 11.17 & 15.68 & 11.05 & 15.15 & 11.26 & 12.38 & 12.05 & 13.60 \\
\hline Tran 2012 & 9 & Methadone & 370 & 12.70 & 14.58 & 11.44 & 14.11 & 12.24 & 13.65 & 14.51 & 15.00 \\
\hline Wang 2012 & 18 & Methadone & 368 & 21.91 & 24.79 & 17.33 & 20.08 & 12.28 & 13.73 & 27.96 & 31.49 \\
\hline Chen 2012 & 3 & Methadone & 127 & 12.37 & 13.63 & 11.21 & 12.52 & 12.01 & 12.03 & 12.41 & 13.19 \\
\hline $\begin{array}{c}\text { Dhawan } \\
\text { and } \\
\text { Chopra } \\
2013 \\
\end{array}$ & 9 & BPN & 231 & 50.3 & 61.3 & 43.6 & 57.9 & 45.8 & 56.2 & 42.3 & 54.3 \\
\hline $\begin{array}{c}\text { Present } \\
\text { Study }\end{array}$ & 12 & $\mathrm{BPN}$ & 100 & 59.87 & 75.24 & 58.58 & 72.81 & 40.33 & 57.88 & 48.66 & 57.26 \\
\hline
\end{tabular}

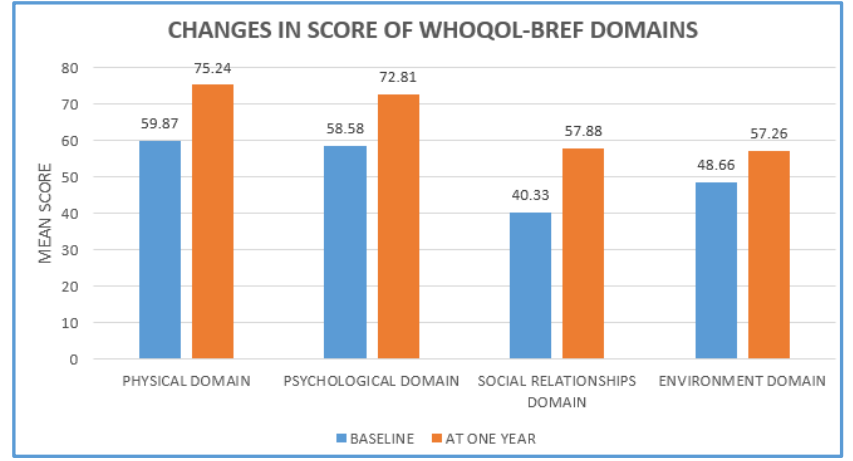

Graph 1. Showing Changes in Mean Score of all Four Domains of WHOQOL-BREF

\section{DISCUSSION}

All (100\%) subjects studied were male, indicating more prevalence of opioid use among males than females and also social stigma of opioid dependence treatment for females in society leading to underutilisation of OST services.

The mean age of the subjects was 30.88 years and mean age of onset of illicit use by subjects was $22.12+4.72$ years. More than half $(65.0 \%)$ of cases were in the age group of 21 . 30 years indicating early age of onset of opioid use. In a study, it was found that of all subjects 30 (36.1\%) were in the age group of 20 - 25 years. ${ }^{11}$ In another study, it was observed that out of 231 subjects most subjects 87 (37.7\%) were in age group of 31 - 40 years and mean age of subjects was 35.3 years. ${ }^{3}$ Another study found that the mean age of subjects was 38.4 years. ${ }^{4}$ Literacy level does not seem to be a protective factor in prevention of opioid dependence and injecting drug use. In a study done in India, it was found that $73(31.6 \%)$ subjects were educated up to high school. ${ }^{3}$ In a study done in Malaysia, it was found that 65 (53.3\%) subjects studied up to senior secondary level. ${ }^{4}$ More than three-fourth subjects were employed. This may be due to beneficial impact of OST on employability of subjects. In a study, an observation was that majority of subjects 96 (78.7\%) were full-time employed. ${ }^{4}$ An Indian study found that 91 (39.4\%) subjects were unemployed and $140(60.6 \%)$ were employed. ${ }^{3}$ Nearly, equal number of subjects were either married or single. This may be indicating deleterious effects of social stigma of opioid use on matrimonial alliance of subjects. Similarly, a study done in India found that 124 (53.7\%) subjects were married. ${ }^{3}$ Majority of subjects lived in a joint family. This may be due to 65 percent subjects of being in the age group of 21 - 30 years, 46 percent subjects being unmarried and cultural and family support factors in India. Mean total duration of Opioid use was $6.37 \pm 4.32$ years. An Indian study concluded that mean duration of substance dependence was $11.13 \pm 8.03$ years. ${ }^{12}$ This was in contradiction to two earlier studies conducted in India, which showed the duration of dependence with findings of mean duration $8.78 \pm 7.79$ years and $5.82 \pm 4.39$ years. ${ }^{13,14}$ Drop- 
out rate was nearly one-third at one year. More dropouts occurred during first 3 months. Similarly, it was found in an earlier Indian study that $64.1 \%$ subjects could be retained at nine months, most drop-outs occurred during the first three months. ${ }^{3}$ In a survey conducted in Punjab 99\% subjects were male, $89 \%$ were literate, $54 \%$ were married, $83 \%$ were employed, 53\% were Heroin dependent and 33\% were IDUs. ${ }^{15}$ In a study conducted by NACO during 2014 - 15, $84.2 \%$ IDUs were literate, $48.3 \%$ never married and median age of initiation of drug use was 19 years and of IDU was 22 years. ${ }^{16}$

Table no. 2 and Graph no. 1 shows that there is improvement in all the four domains i.e. physical, psychological, environment and social relationships from baseline till the end of the study, i.e. one year. Statistically significant $(p<0.01)$ improvement in all four domains viz. physical, psychological, social relationships and environment was found when baseline scores were compared to scores at one year of follow-up, indicating positive impact of OST on quality of life of IDU opioid dependents. This is consistent with earlier studies done on quality of life among OST subjects. Table no. 3 compares the findings of present study with similar previous studies on all four domains of WHOQOL-BREF.

\section{CONCLUSION}

In summary, the present data indicates that buprenorphine is a useful long-term maintenance treatment for opioid dependent patients. So OST programmes should be expanded further. The results may be useful for scaling up of maintenance programme for curbing injecting drug use and improving quality of life.

\section{Limitations of the Study}

There are few limitations pertaining to this study. The results should be interpreted in the light of these shortcomings. Sample size of the study was limited. Thus, there is a need for larger sample size to assess quality of life among injecting drug users. No control group was taken in the study for comparison. The subjects who dropped out from study were not followed-up. Since no data were collected after disenrollment, their fate is unknown. It is imperative to study the reasons for dropout in these subjects. It will also be worthwhile to know the overall outcome of quality of life in these subjects.

\section{REFERENCES}

[1] Rao R, Aggarwal A, Ambekar A. Opioid substitution therapy under national AIDS control program. Clinical practice guidelines for treatment with Buprenorphine. Department of AIDS Control, Ministry of Health \& Family Welfare, Govt. of India, New Delhi. 2014.
[2] The world health organization quality of life assessment (WHOQOL): position paper from the World Health Organization. Soc Sci Med 1995;41(10):1403-9.

[3] Dhawan A, Chopra A. Does buprenorphine maintenance improves quality of life of opioid users? Indian J Med Res 2013;137(1):130-5.

[4] Baharom N, Hassan MR, Ali N, et al. Improvement of quality of life following 6 months of methadone maintenance therapy in Malaysia. Subst Abuse Treat Prev Policy 2012;7:32.

[5] Wang PW, Wu HC, Yen CN, et al. Change in quality of life and its predictors in heroin users receiving methadone maintenance treatment in Taiwan: an 18month follow-up study. Am J Drug Alcohol Abuse 2012;38(3):213-9.

[6] Lua PL, Talib NS. A 12-month evaluation of healthrelated quality of life outcomes of methadone maintenance program in a rural Malaysian sample. Subst Use Misuse 2012;47(10):1100-5.

[7] Musa R, Abu Bakar AZ, Ali Khan U. Two-year outcomes of methadone maintenance therapy at a clinic in Malaysia. Asia Pac J Public Health 2012;24(5):826-32.

[8] Tran BX, Ohinmaa A, Duong AT, et al. Changes in drug use are associated with health-related quality of life improvements among methadone maintenance patients with HIV/AIDS. Qual Life Res 2012;21(4):613-23.

[9] Dvoryak S, Grishayeva I. First experience of opioid therapy with buprenorphine in Ukraine. Heroin Addict Relat Clin Probl 2008;10:13-8.

[10] Chen CY, Ting SY, Tan HK, et al. A multilevel analysis of regional and individual effects on methadone maintenance treatment in Taiwan. Value Health 2012;15(1 Suppl):S60-4.

[11] Lashkaripour K, Bakhshani NM, Sadjadi SA. Quality of life in patients on methadone maintenance treatment: a three-month assessment. J Pak Med Assoc 2012;62(10):1003-7.

[12] Kalra I, Bansal PD. Sociodemographic profile and pattern of drug abuse among patients presenting to a de-addiction centre in rural area of Punjab. Delhi Psychiatry Journal 2012;15(2):327-31.

[13] Mattoo SK, Nebhinani N, Kumar BN, et al. Family burden with substance dependence: a study from India. Indian J Med Res 2013;137(4):704-11.

[14] Nebhinani N, Anil BN, Mattoo SK, et al. Family burden in injecting versus non injecting opioid users. Ind Psychiatry J 2013;22(2):138-42.

[15] Opioid Dependence Survey (PODS) - pbhealth.gov.in www.pbhealth.gov.in/scan0003(2).pdf.

[16] National AIDS Control Organization. State epidemiological fact sheets - Volume 1, North-East Region 2017. New Delhi: NACO, Ministry of Health and Family Welfare. Government of India, 2017. 